\title{
Journalism as a Public Political Agenda
}

\author{
Dudi Iskandar
}

\begin{abstract}
Contemporary journalism is changing dramatically. The main trigger is the development of communication technology, especially the internet. Public involvement in building issues on social media has changed news production. Because of the presence of internet journalism which originally was the process of searching for news (active), now turned into receiving news (passive). With a qualitative approach and a critical paradigm, this study uncovers how the journalism changes. Journalism is now changing from the construction of the reality of media politics to the construction of the reality of the media public agenda. The public builds a political agenda through invitation coverage, disseminates press releases, social networks, and embodied to political actors. Some of the basic assumptions of this theory are the construction of the reality of the public political agenda. First, the public constructs an agenda for their political interests. Second, the public encourages and convinces the media that its political agenda is important to the other public. Third, the public political agenda must be in line with the media-political agenda. With the construction of reality, the real powerful political agenda is public. While the media is weak because it is only a tool and has the same interests as the public political agenda. The construction theory of the public political agenda is contrary to the agenda-setting theory.
\end{abstract}

\section{Index Terms: Journalism, Internet, Public Political Agenda}

\section{INTRODUCTION}

Along with the development of communication and information technology, the definition of journalism is constantly changing. Journalism is a business, skill, or practice of producing and disseminating information about public affairs which is warm and important (Michael Schudson, 2003: 11). This business is regulated by an institution or organization professionally. The information presented by journalism is a fact that occurs in the field so that the truth of an event can be captured by the people who receive the information.

According to Denis Mcquail (2013: 1-2), journalism is often equated with news, mass media, the press, and newspapers. Although there are differences between these terms. Journalism refers to professional activities or outcomes involved in gathering, analyzing, and publishing news. News can be defined as stories of actual events that are relevant to the public interest.

The main product of journalism work is news. News is writing, impressions, or broadcasts about the facts of an event or event that is published or broadcast by the mass media using a $5 \mathrm{~W}+1 \mathrm{H}$ construction (What, Why, Who,

Revised Manuscript Received on September 22, 2019

Dudi Iskandar, Lecturer of Communication Science Faculty of Budi Luhur University, Jakarta. dudisabiliskandar@yahoo.com
Where, When and How). The $5 \mathrm{~W}+1 \mathrm{H}$ principle has now evolved to $6 \mathrm{~W}+1 \mathrm{H}$ with the addition of the $\mathrm{W}$ sixth What Next. This sixth principle emerged later, the emergence of online media which pursued the speed of an event.

The development of information and communication technology, especially the internet, the definition of journalism and news has shifted again due to the presence of social media. Social media is a means, source, and involved in the process of journalism. Almost no issues, discourses, and events escaped the dynamics of social media. Citing sources from social media has become a trend in the latest journalism. Thus, a very significant shift occurred in the journalistic process. The spread of discourses and events is not only through mass media. Journalism and news are reviewed not only from the perspective of the medium but from the perspective of the product. As long as the writings and shows of events have journalistic rules, they are worthy of being called news or journalistic products.

The technology of information and communication and social transformation that accompanies journalism has pressured journalists to record a variety of questions that have never existed before. Who is the reporter? What is done for the community? Do journalists voice unique social roles of society and so on (Wilson Lowrey and Peter J. Gade (ed), 2011: 214).

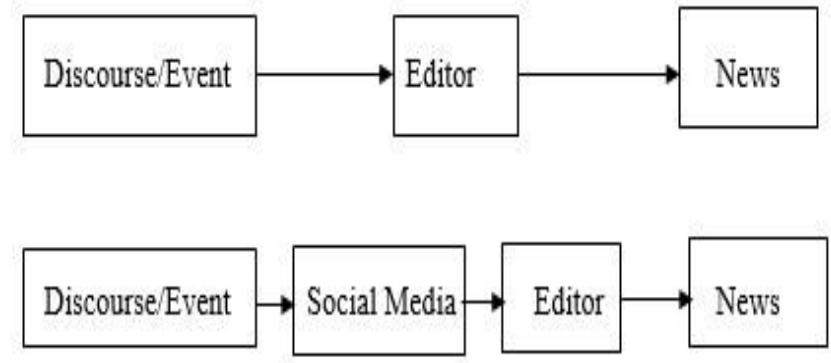

Fig 1 Changing of Journalism Model

In contemporary reality, there is nothing independent, including media organizations. Media editors cannot be separated from a variety of interests that influence and surround them. Editorial decisions may not be without involving the voice of the founder, owner, or shareholder. In fact, the voice of founders, owners, or shareholders is not included in the editorial ranks, but current journalism, especially business-economic and political-power news, cannot possibly ignore their letters. Especially if the founder, owner, or shareholder has an entrepreneur or politician background. Thus, in the reality of today's journalism, there is a shift from independent to interdependence. 


\section{LITERATURE REVIEW}

\section{A. Journalism and Political Agenda}

There are three political communicators version of Dan Nimmo (1989). Politicians, professionals, and activists. However, the present reality adds a political communicator; the mass media. The media on the contemporary political stage is increasingly irreplaceable. Now the role of the media goes beyond what political parties can do in a conventional way. It can be seen from how the political elite issues its discourse and ideas through the media. At a certain stage, the media has become a political actor. As a political actor, he can issue or hold issues that benefit or harm other political actors. The formation of public opinion occurs, who has access to the media, he who controls opinion.

The reality of contemporary journalism shows its significance and truth. That the role of the media in today's political field has changed greatly. The media is not only a social and economic or business institution. It also, as an institution, is now one of the political communicators as stated by Brain McNair (1995) and Ignatius Haryanto (2014: 72).

Today's media owners are not patient people in long-term investing. They seek profits as soon as possible by utilizing closeness to power. Close to power, close to financial resources. For close political power needs to have in other forms of power. Today, another very powerful power is the media. Therefore, if political power and media power unite, synergize, then money will automatically flow. This is the simple formula. Media is indeed not a neutral domain where various interests and meanings of various groups will receive balanced treatment. Media is a subject that constructs reality based on its own interpretation and definition to be disseminated to the public (Danny Schechter, 2007: 3).

Media conglomeration is increasingly hegemonic and finds its momentum along with the ideology of capitalism entering the world of journalism. According to Yasraf Amir Piliang (2011: 85), there are four main elements of global capitalism, time, space, money, and speed. This acceleration and speed have damaged and penetrated also into journalism. The speed and acceleration dragged journalism into the vortex of global competition. This is where the flames of capitalism burn the great value of journalism. News as the main element or pillar or core of journalism has become a commodity. (Ignatius Haryanto, 2014: 71). By becoming a commodity, the news is losing vitality. It is only a tool to generate finance. News is no longer a producing discourse that enlightens and builds community awareness. The news falls into dictation by the power of capital. The result is information manipulation for the benefit of the group. Not only provides financial benefits but also has a hidden agenda

\section{B. Political Construction and Public Agenda}

The construction of reality begins with the sociological theory of knowledge by Peter L. Berger and Thomas Luckmann (1979). They define the understanding of reality, knowledge in the context of social interaction. In political journalism, the construction of political reality was built by the media. But along with the changing reality and development of technology, the internet, which allows everyone to create a political agenda, the public involvement in the journalism process is true. The public defines reality, has an agenda and political interests.

\begin{tabular}{|c|c|c|}
\hline Public & Method & News \\
\hline 1. Politicians & Invitation, & \multirow{5}{*}{$\begin{array}{l}\text { News } \\
\text { construction is } \\
\text { adapted to the } \\
\text { subject of the } \\
\text { sender and the } \\
\text { interests of the } \\
\text { public political } \\
\text { agenda. }\end{array}$} \\
\hline 2. Political & press release & \\
\hline $\begin{array}{l}\text { Parties } \\
\text { 3. NGOs }\end{array}$ & $\begin{array}{l}\text { Network and } \\
\text { invitation }\end{array}$ & \\
\hline $\begin{array}{l}\text { 4. Community } \\
\text { Organization } \\
\text { s } \\
\text { 5. Candidate }\end{array}$ & $\begin{array}{l}\text { Event, } \\
\text { Invitation, } \\
\text { and press } \\
\text { release }\end{array}$ & \\
\hline $\begin{array}{l}\text { campaign } \\
\text { teams } \\
\text { 6. Companies }\end{array}$ & $\begin{array}{l}\text { Invitation and } \\
\text { embedded }\end{array}$ & \\
\hline
\end{tabular}

Fig 2 Public Envolvement in Journalism

A political campaign is a tool to inculcate political parties and candidates' political agenda into the public mind. In a democratic country, the campaign becomes a given for granted to get public support. So, the media campaigned and also became one of the tools for the campaign. It has the ability to convey political messages to audiences directly so that public opinion is formed. Anwar Arifin (2010: 11-13) defines public opinion as to the same opinion and expressed by many people obtained through intensive discussion in response to questions and problems concerning public interests. There are three elements in public opinion. That is an actual issue and concerns the public interest, which is broadcasted by the media, there are a number of people discussing it, and that opinion is expressed through oral, written and gesture. E. Rogers and Shoemaker stated that there were five stages of the development of public opinion caused by mass media. Awareness, attention, evaluation, trial and error, and adoption. Awareness and attention are the main doors to the entry of media influences which then shape public opinion. (Anwar Arifin, 2010: 91).

The establishment of positive public opinion is inseparable from precision in developing a political communicator strategy in four ways, namely, understanding audiences, compiling persuasive messages, setting methods, and selecting and sorting media. Understanding audiences means separating or verifying the objectives of the political message that political communicators offer based on geography, demographics, psychographics, and behavior, and socio-cultural variables. With the segmentation of audiences, political communicators are increasingly easy to compile political messages that hit or are embedded in the minds and hearts of voters. A good message is in accordance with the characteristics of the target.

Submitting a political message to a segmented audience will not be effective if it fails in choosing a method for delivering political messages from political communicators. Therefore, a good method determines the results of political imaging. However, the three-step political communicator is likely to fail if one chooses and sorts the media. 


\section{METHODOLOGY}

This paper begins by describing the reality of media and contemporary journalism. After that, it shows various theories that underlie the need for a new perspective in media studies and journalism. Then presents an offer in examining the reality of contemporary journalism. Finally, discussing the perspective as an alternative in reviewing media and journalism today.

The approach used in this study is qualitative. Data collection is done through library research and analysis of library data (documents) and critically analyzing the phenomenon and reality of media and contemporary journalism. Library research (document analysis) is one way to extract data from books, journals, and or sites according to the themes discussed in this paper.

\section{RESULT AND FINDINGS}

The character and formulation of journalism are fundamentally changing. The key word of the transformation of journalism is the change in communication and information technology. That is very influential in journalistic practice activities and professional access. Especially internet technology has triggered journalism in two ways, speed and space, diversity, interaction, and participation (Stuart Allen (ed), 2010: 557). Freedom of opinion, interaction, and creation through the internet creates a phenomenon of freedom that has never happened before. Freedom in a virtual world without space and time constraints is real. This also happens in the world of journalism. Therefore, news must be redefined from propositions to serve the public to respect for individuals in their use and satisfaction with the media and medium (Rachel Davis Mersey, 2010: 93).

The presence of online journalism or news sites clearly and decisively alters the various habits and mechanisms of print media. In print media, editorial meetings are held every day, at least twice. This happens because it has a long free time to process and reduce a story. Whereas on a news site that has a real-time /update domain it is not possible to do this. In the editorial meeting or the determination of news, the sound of the media depends on macro policies. No partial, or one or two news, but the overall nature of a strategic nature, in accordance with the vision and mission of the media. Therefore, it can be ascertained that editorial individuals already know and understand the strategies and policy lines of the founders, owners, or shareholders.

Changes in the pattern of journalism from another perspective occur. That journalism has now turned into new internet-based media journalism. In this model of journalism, community participation is a necessity. New media journalism can only live in a networked society. The development of a new approach to journalism research is described by Ari Heinonen (1999: 85) as contained in the figure below.

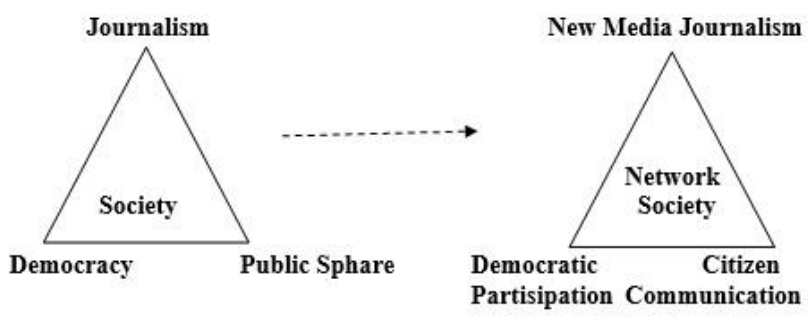

Fig 3 Approach for Journalism Research in the Information Society

Another research finding is that there is a strong correlation between political alignments and journalism products (news). Political alignments resulted in journalistic products are being destroyed. The existence of ethical neglect in every journalistic product increasingly explains that journalism is now on the verge of collapse or must be the emergence of a new genre of journalism. Journalism is experiencing a crisis. (Yasraf Amir Piliang, 2010: 69-70)

The current condition of journalism makes journalism lose its noble spirit. Also, uprooted from the root of authenticity; losing his idealism. The ideological content which is very thick with economic interests and political power makes the news lose its vitality as a provider of health information for the community; public dialectic space; indicators of democratic progress for this nation and country. Journalism loses responsibility due to inaccuracies, neglect, and stereotypes (Karen Sanders, 2004: 154). The credibility crisis in journalism is a very significant challenge when so much news in the media has a source of information. To care for the audience the media must show quality and have value before them (Wilson Lowrey and Peter J. Gade (ed), 2011: 23-24).

Journalism, which was originally a process of finding data and active position, now in the reality of contemporary politics the media becomes passive and receives data from the public. In this context, the discourse built by the media is the construction of the reality of the public political agenda. There are some basic assumptions about the construction of the reality of the public political agenda. First, the public constructs an agenda for their political interests. Second, the public encourages and convinces the media that its political agenda is important for the external public. Third, the public political agenda must be in line with the media-political agenda. With the construction of reality, the real powerful political agenda is public. Whereas the media is 'weak' because it is only a tool and has the same interests as the public political agenda.

The construction of the public political agenda is contrary to the agenda-setting theory (McCombs and Donald Shaw, 1972). Both explain the symptoms or phenomena of election campaign activities. Agenda setting theory is closely related to mass communication and news production (E.M. Griffin. 2003: 359-371). According to both agenda, settings is the ability of mass media to send the importance of an issue in their news agenda to the public agenda. 
Media may not be very successful in dictating to people what to think about (what to think) but the media is great at successfully dictating to the audience what to think about (what to think about). This theory holds that the press has great power.

The agenda setting theory is built on the assumption that there is a causal relationship between media content and audience perceptions. The research conducted by both shows that there is a strong influence from the media priority agenda that considers something that is important to the public. This then shows there is a match between the media agenda and the public agenda. In view of the agenda setting, it is not the media influence that determines the actions of the audience but there is a kind of causal relationship that occurs. It is at this point that the media is able to influence the audience through its agenda so that the perception of the audience will be the same as the perception built by the media. The basic assumption of the set agenda is first, the press community and mass media do not reflect reality; they filter and shape issues. Second, the concentration of mass media is only on a number of community issues to be shown as more important issues than other issues.

\section{CONCLUSION}

Changes in journalism are inevitable. In history, the pattern of journalism has changed according to the development and presence of communication and information technology. The pattern of print media journalism is different from broadcast media. Likewise, the presence of the internet has turned journalism into an online. Both are different from print media journalism and broadcast media. The presence and massive use of the internet by the public changes the production of news. Because of the presence of internet journalism which at first was the process of searching for news (active) and now turned into receiving news (passive).

\section{REFERENCES}

[1] Allen, Stuart (Ed). 2010. The Routledge Companion to News and Journalism. London. Routledge

[2] Arifin, Anwar. 2010. Opini Publik, Depok: Gramata. 2011. Komunikasi Politik; Filsafat-Paradigma-Teori-Tujuan-Strategi. Yogyakarta: Graha Ilmu.

[3] Bell, Allan and Peter Garret (ed). 1998. Approaches to Media Discourse. Oxford Blackwell Publishers.

[4] Berger, Peter L. Dan Thomas Luckmann. 1979. The Social Construction of Reality: A Treatise in The Sociology of Knowledge. Middlesex: Penguin Books.

[5] Griffin, EM. 2012. A First Look at Communication Theory. Eight Edition. New York. Mc. Graw Hill.

[6] Haryanto, Ignatius. 2014. Jurnalisme Era Digital; Tantangan Industri Media Abad 21. Jakarta: Kompas Media Nusantara.

[7] Heinonen, Ari. 1999. Journalism in the Age of Net; Changing Society, Changing Profession. University of Tampere, Finland

[8] Lowrey, Wilson and Peter J. Gade (ed). 2011. Changing the News; The Forces Shaping Journalism in Uncertain Times. London. Routledge.

[9] McNair. Brian. 1995. An Introduction to Political Communication. Second Edition. London. Routledge 2000. Journalism and Democracy; An Evaluation of the Political Public Sphere. London. Routledge.

[10] Mcquail, Denis. 1987. Teori Komunikasi Massa. Second Edition. Translator Agus

[11] Dharma dan Aminuddin Ram. Jakarta. Erlangga. 2013. Journalism and Society. New Delhi, Sage Publications India.

[12] Nimmo, Dan. 1989. Komunikasi Politik: Komunikator, Pesan dan Media, translator Tjun Surjaman. Bandung. Remaja Rosdakarya.
[13] Piliang, Yasraf Amir. 2010. Post-realitas; Realitas Kebudayaan dalam Era Post-metafisika. Cetakan III. Yogyakarta. Jalasutra 2011. Dunia yang Dilipat. Cetakan 1. Bandung. Matahari.

[14] Schechter, Danny. 2007. Matinya Media; Perjuangan Menyelamatkan Demokrasi. translator Gita W. Jakarta. Yayasan Obor.

[15] Schoemacher, Pamela J and Stephen D. Reese. 2014. Mediating the Message: Theories of Influences on Mass Media Content. Third Edition. New York. Routledge

[16] Schudson, Michael. 2003. The Sociology of News. The USA. W.W. Norton \& Campony Inc.

\section{AUTHORS PROFILE}

I am Dudi Iskandar, and Lecturer of Communication Science Faculty of Budi Luhur University, Jakarta. My area of interest is science and technology. dudisabiliskandar@yahoo.com. 